$1-4-2019$

\title{
Governance structure and performance of private family firms
}

Tarun Mukherjee

Vighneshwara Swami

Wei Wang

Cleveland State University, w.wang24@csuohio.edu

Follow this and additional works at: https://engagedscholarship.csuohio.edu/bus_facpub

Part of the Corporate Finance Commons, and the Finance and Financial Management Commons How does access to this work benefit you? Let us know!

Publisher's Statement

This is the accepted and peer-reviewed version of a work appearing in the Journal of Economics and Finance. The final publication is available at Springer via https://doi.org/10.1007/ s12197-018-9466-6

\section{Recommended Citation}

Mukherjee, Tarun; Swami, Vighneshwara; and Wang, Wei, "Governance structure and performance of private family firms" (2019). Business Faculty Publications. 282.

https://engagedscholarship.csuohio.edu/bus_facpub/282

This Article is brought to you for free and open access by the Monte Ahuja College of Business at EngagedScholarship@CSU. It has been accepted for inclusion in Business Faculty Publications by an authorized administrator of EngagedScholarship@CSU. For more information, please contact library.es@csuohio.edu. 


\title{
Governance structure and performance of private family firms
}

\author{
Tarun Mukherjee $\quad$ - Vighneshwara Swami · Wei Wang
}

\begin{abstract}
A debate exists on the issue of whether a governance system is value additive or even necessary for a privately-held firm. One side of the debate suggests that, since agency problems do not exist in a small private firm, it does not need a costly governance system. The other side argues that a private firm indeed faces agency costs in the form of altruism and, therefore, could extract net gains from a governance system. In this paper, we empirically investigate whether a good governance system crates or destroys value of private family firms. We first demonstrate that a multifamily firm encounters larger agency costs stemming from inter-family conflicts, and therefore, has larger incentive than a single-family firm to institute a superior governance system. We then show that a multifamily firm, owing to its better governance system, outperforms its single-family counterpart.
\end{abstract}

Keywords Family firms $\cdot$ Ownership structure $\cdot$ Financial performance $\cdot$ Governance

\section{Introduction}

According to Jensen and Meckling (1976), a privately held firm managed by a single owner will not incur agency costs as the conflicts of interest between the manager and 
the owner do not exist. Conflicts might arise when the firm is owned by multiple owners, However, such conflicts would be efficiently resolved as economically rational owners have incentives to do so. Thus, formal governance mechanisms are not only unnecessary but might be value reducing for private firms.

Schulze et al. 2001 (hereafter SLDB) challenge the notion that the agency cost of conflicts among owners is insignificant based on the argument that owners are exclusively motivated by economic rationale. They argue that preferences are not expressed in economic terms alone but in non-economic terms as well and people seek to maximize the utility they gain from both. A major driver of the non-economically motivated behavior is altruism which "allows the individual to simultaneously satisfy both altruistic (other-regarding) preferences and egotistic (self-regarding) preferences" (p. 102). The second type of altruism, the threat of self-control, often expressed in the forms of providing secure employment as well as perquisites and privileges to family members, is an important source of agency costs for a private firm. SLDB posit that such a self-control problem "is particularly troublesome when privately held firms are owned and managed by family" (page 102). This is because control over the firm's resources makes it possible for a family owner-manager "to be unusually generous to their children and relatives" (page 103). Therefore, self-control and altruism together create a distinct set of agency problems for family-owned private firms, threatening their performance. ${ }^{1}$ According to SLDB (2001), a good corporate governance system is needed for private firms since additional costs of governance will outweigh the costs of self-control and altruism. Uhlaner et al. (2007) also suggest (in reference to private firms) that the governance plays a comprehensive role in holding management accountable, reducing downside risks, and enabling the firm to achieve its upside potential.

To sum up, the two theories offer opposite implications regarding the role of governance for private firms: Jensen and Meckling (1976) suggest that governance system is costly, and therefore, value reducing for private-held family firms, while SLDB (2001) conclude that the benefits of the governance system outweigh its costs. In this paper, we perform an empirical analysis to investigate whether a good governance system crates or destroys value of privately-held small family firms.

According to SLDB (2001), both single-family as well as multiple-family ${ }^{2}$ owned private firms can benefit from a good governance structure. However, a founder-owner of a single-family firm might prefer maintaining control of the firm to its performance, and thus, is less likely to impose a governance system on himself. After reviewing pertinent literature, Daily and Dalton (1992) comment: "Extant research would suggest that founder CEOs rely on dysfunctional governance structures (e.g., CEO duality, lower numbers of outside directors, lower proportions of outside directors) to a greater extent than their nonfounder counterparts" (p. 375). Thus, Daily and Dalton (1992) argue that a firm run by a founder-manager is likely to be associated with decreased firm performance. ${ }^{3}$

\footnotetext{
${ }^{1}$ Other reasons that might impact the performance of private small firms is their inability to provide competitive compensation and promotional opportunities, resulting perhaps in hiring employees that are likely inferior to those hired by a publicly held firm.

${ }^{2}$ We define "family firm" as a private business that is solely owned and controlled by the founder (i.e. singlefamily) or by descendants of the founder (i.e., multifamily).

${ }^{3}$ Although Daily and Dalton's statement is in the context of publicly-held firms, it might equally apply to the founder-manager of a privately-held firm. Who, for personal reasons as well as being exempt from the market disciplining mechanisms, avoids a governance system that interferes with his control or questions his decisions.
} 
A multifamily firm, on the other hand, has higher agency costs than a singlefamily firm, especially because of potential conflicts of interest among the owners. According to Dyer Jr (2006), the higher agency costs of a multifamily firm result "from opportunism, shirking, and adverse selection because of altruism (i.e., family members fail to monitor each other)" (p. 259). Jaffe and Lane (2004) note "Many times, a family branch that is not as involved feels as though an inside group has taken unfair advantage of the family business by reaping greater benefits for its own branch" (page 12). The possibility of agency conflicts in the context of multifamily firms is also discussed in intergroup theory that is primarily concerned with discords (Tajfel 1982a, b, Tagiuri and Davis 1996) between in-groups ('us') and out-groups ('them'). This theory suggests that whenever two or more groups come together, one will try to overpower the other to either gain control or acquire an advantage over the other, which inevitably results in conflicts (Tajfel and Turner 1979).

Given that agency problems are more acute in a multifamily firm, it may be argued that such a firm would have a greater incentive (than a single-family firm) to reign in agency costs via mutually agreed upon formal or informal governance system. Existing research supports this notion. For example, Uhlaner et al. (2007) state "a shift from a founder-owner-managed firm to a multiple ownership structure may result in immediate demands for more accountability and in turn, more formal governance mechanisms" (p. 23). While describing stages of family business evolution (see Appendix 1), Jaffe and Lane (2004) classify family partnership as Generation 2 (maturing business) that requires an informal board and Generation 3 (family dynasty) that requires a formal board with outsiders. The authors suggest that appropriate governance structures are needed to optimize these relationships.

In this paper, our first objective is to investigate if multifamily firms do indeed have a better governance structure than single-family firms. There is plenty of evidence in the finance literature of a positive relationship between the quality of a firm's governance system and its performance, especially for publicly-held firms. SLDB report similar results pertaining to smaller private firms as well. If indeed the multifamily firms are associated with better governance, the logical question that follows is whether these firms outperform singlefamily firms. Thus, the second objective of the paper is to answer this question. Even if a strong positive association between multifamily ownership and the firm performance is found, the result does not necessarily imply that the superior performance is an outcome of a superior governance system. Consequently, our parallel objective is to investigate whether the superior performance of the multifamily firms is a direct result of their superior governance structure.

Based on the above discussion, we formulate the following hypotheses:

1. Governance structure of a multifamily firm is superior to that of a single-family firm;

2. Multifamily firms are better performers than single-family firms; and the superior performance is a direct result of the higher quality of corporate governance. 
Employing a hand-collected sample of private family-owned small firms in India we test the hypotheses posed above and find that multifamily firms significantly outperform single-family firms and the superior performance is attributable to the better governance system of the former group.

The paper proceeds along the following lines. In section II, we present methodology of the paper, including the sample, variables and data. Section III discusses results, while Section IV concludes.

\section{Sample, variables, data \& methodology}

\subsection{Sample}

Our sample covers unlisted family-owned small firms (UFOSFs) in India and provides a distinct laboratory to perform our experiment. The UFOSFs are scattered all over India. However, since the information needed for our paper had to be hand collected, we limit our sample to the firms that belong in the provinces closer to the university where one of the authors teaches. Students of this university administered a questionnaire in person during their 2011 summer internship program. Our final sample consists of 83 firms of which 51 are single-family firms and 32 are multifamily firms. ${ }^{4}$

In Jaffe and Lane (2004) paradigm (Appendix 1), our single-family firms fall in Generation 1, which are entrepreneurships with founder-managers, and multifamily firms fall in a broader spectrum of Generation 2, which are family partnerships owned and managed by sibling teams. Although small, our sample closely mirrors, to the extent possible, the UFOSF population, especially in terms of geographical, demographical, cultural, and industrial diversities. Appendix II shows that the sample represents all five geographical regions of India.

Table 1 presents selected characteristics of the sample firms. Assets are below 100 million Indian rupees (INR) for 59 sample firms (42 single-family and 17 multifamily), between 100 million and 500 million INR for 14 firms (4 single-family and 10 multifamily), and greater than 500 million INR for the remaining 10 firms (5 single-family and 5 multifamily). Fifty firms in the sample are from manufacturing industries such as chemicals, consumer goods, steel and textiles, 22 are involved in the services activities such as financial services, hotels, and packaging, and 11 from other industries. Although not shown in the table, the ownership of multifamily firms is divided equally among all of the families, perhaps signifying that the owners are direct descendants of the founder.

\footnotetext{
${ }^{4}$ Private family-owned firms in India has so far been outside the scope of academic investigation as prior studies such as Khanna and Palepu (2000) and Gopalan et al. (2007) examine publicly-listed Indian firms that are usually larger and with scattered ownership structure.
} 
Table 1 Ownership by the asset size and industry type

\begin{tabular}{|c|c|c|c|c|c|c|}
\hline & Single-family & Multifamily & Two families & Three families & $\begin{array}{l}\text { More than } \\
\text { three families }\end{array}$ & Total \\
\hline All firms & 51 & 32 & 5 & 7 & 20 & 83 \\
\hline \multicolumn{7}{|l|}{ Asset classes } \\
\hline Below 100 million $\mathbb{I N R}$ & 42 & 17 & 3 & 5 & 9 & 59 \\
\hline $100-500$ million INR & 4 & 10 & 2 & 1 & 7 & 14 \\
\hline Above 500 million INR & 5 & 5 & 0 & 1 & 4 & 10 \\
\hline \multicolumn{7}{|l|}{ Industries } \\
\hline Manufacturing & 38 & 12 & 2 & 3 & 7 & 50 \\
\hline Services & 9 & 13 & 3 & 3 & 7 & 22 \\
\hline Others & 4 & 7 & 0 & 1 & 6 & 11 \\
\hline
\end{tabular}

Exchange rates: March 2008: 1USD=40.22 INR March 2009: 1USD=51.18 INR March 2010: 1USD = 45.48 INR

This table shows the ownership structure of the 83 sample firms. Also presented are the distribution of these firms in categories defined by total assets and industries, respectively

\subsection{Variables}

\subsubsection{Performance measures}

In the absence of market performance measures, such as market-to-book ratio, we employ accounting measures of performance - return on assets (ROA) and return on equity (ROE). These two popular accounting measures in finance research are defined below.

- ROA: Net income/average total assets, where average assets are the sum of the start-of-the-year and the end-of-the-year assets divided by 2 ;

- ROE: Net income/average equity, where average equity is the sum of the start-ofthe-year and the end-of-the-year equity divided by 2 .

\subsubsection{Governance measures}

Jaffe and Lane (2004) relate an ad hoc and implicit governance system to Generation 1 family firms, an informal board and implicit system to Generation 2 and board with outsiders and formal policies to Generation 3 family firms. They identify the following characteristics of good governance: absence of duality, bigger board size, greater number and proportion of independent board members. We add one more dimension to the parameters suggested by Jaffe and Lane (2004) which is the presence of outsider(s) on the audit committee. These variables are elaborated below.

Duality It occurs when a firm's CEO plays dual roles as the Chair of the board. Duality is likely to be a common phenomenon for single-family firms. 
Daily and Dalton (1992), among others, comment that if "maintaining control is imperative , ...., it seems likely that the founder-manager would elect to serve as both CEO and board chairperson. To do otherwise invites some risk of divided authority" (p. 378). A multifamily firm, on the other hand, will likely avoid duality lest it should lead to concentration of power to one family who might use it in detriment of the interests of other families, especially in the absence of an independent board. Thus, we predict that multifamily firms will exhibit a lower incidence of duality (i.e., higher incidences of positions of CEO and Chairman being held by two separate persons) than single-family firms.

Theoretical predictions and/or empirical results on the impact of duality on the performance of large publicly-traded firms are mixed. Fama and Jensen (1983), Lipton and Lorsch (1992) and Jensen (1993) argue that the effect of duality is negative because it lessens board's ability to monitor the CEO. Similarly, Daily and Dalton (1992) refer to duality as one of the "dysfunctional" preferences of the founder-manager. ${ }^{5}$ Jaffe and Lane (2004) too suggest that absence of duality is a sign of good governance. Contrarily, proponents of duality argue that its impact of on firm performance is positive since it promotes an unambiguous leadership and reduces information costs (Anderson and Anthony 1986; Brickley et al. 1997). Berg and Smith 1978, Chaganti et al. 1985, among others, find firm performance to be independent of the duality structure.

Whether duality reduces or augments agency problems in a multifamily firm is a subject of debate as well. On one hand, duality might lead to concentration of power to one family who might use it in detriment of the interests of other families, especially in the absence of an independent board. On the other hand, by selecting the same family to serve in both positions might signify wellplaced confidence and trust other families have in this family: the confidence should be reflected in the improved performance of the firm. Because of opposing arguments, we refrain from predicting the sign of duality and allow it to be determined empirically.

Independent directors A single-family firm is likely to have fewer if any, independent board members. According to Daily and Dalton (1992), notwithstanding "the series of recommendations advocating an independent board structure and the addition of outside board members, the founder CEO may perceive such a strategy as potentially threatening" (p. 378). Thus, the board of a founder-managed firm is less likely to be represented by independent members.

The presence of independent board members, however, will be preferred by owners of multifamily firms to reduce the possibility of one family from taking advantage of another. Jaffe and Lane (2004) recommend representation of independent members on the board of multifamily businesses. Thus, we expect that the board of multifamily

\footnotetext{
${ }^{5}$ Daily and Dalton (1992), however, do not find a significant difference in the governance structure between publicly-held founder-CEOs and non-founder-CEOs.
} 
firms will consist of a larger percentage of independent directors than that of singlefamily firms.

The role of independent directors in improving the performance of a large publicly held firm has long been a subject of debate. Some researchers (for example, Chaganti et al. 1985; Rosenstein and Wyatt 1990, Anderson and Reeb 2003) find the role to be insignificant. Ferris et al. (2003) find that outside directors with multiple board appointments may be too busy to mind the businesses. Indeed, Vance (1968) reports that it is the firm with an inside dominated board that performs better than an outside dominated board. On the other hand, Bhagat et al. (2008) suggest that independent directors are the crucial monitoring mechanism that might contribute to better firm performance and Nguyen and Nielsen (2010) offer specific evidence to indicate that independent directors improve a firm's performance.

In regard to small businesses, Jaffe and Lane (2004) comment that an independent board is "a key business source for successful operations" ( $p$. 14). Vance (1983), among others, argues that outside directors provide a monitoring function. However, the board of a founder-managed firm is less likely to be represented by independent members. Even when "independent" members are represented on the board, it is not sure if it will have its intended impact on the firm's performance: Castaldi and Wortman (1984) suggest that the owner-manager might not embrace the advice of the outside board members. Owners of a multifamily firm have the incentive to seek out independent board members to lessen the agency problem. The monitoring functions of independent directors will likely lead to these firms performing better than single-family firms. We measure independent director (\%Outside directors) as the percentage of independent board members relative to the total number of members on the board.

Board size The argument advanced Daily and Dalton (1992) about founderCEO's reluctance to invite outside board members equally applies to size of the board: a single-family firm is likely to prefer a board that is small and often in compliance with the owner's decision. In comparison, multifamily firms would likely have a larger board than that of single-family firms. There are at least two reasons in favor of this argument. First, the bigger board size inevitably results from the greater need for independent directors in a multifamily firm. Second, it is highly likely that each family in a multifamily firm would put its own representative on the board, making the board size larger.

The extant work predominantly suggests that smaller board size is more effective than larger board size, especially for publicly-held firms because the problems with coordination and processing overwhelm the advantages gained from having more people to draw on (Steiner (1971) and Gersick and Hackman (1990)). Lipton and Lorsch (1992) suggest that large boards can be less effective than small boards, and recommend limiting the size to seven or eight people on the board. Jensen (1993) suggests that larger board size could be detrimental to efficient decision making, thus entailing an adverse impact on the firm performance. Two main sources of the potential negative effect are 
a) increasing problems of communication and coordination and b) decreasing the ability of the board to monitor managerial actions.

Empirical results have generally been consistent with a negative relation between the board size and firm performance (e.g., Yermack 1996; Eisenberg et al. 1998; Mak and Kusnadi 2005, Sanda et al. 2005) in the context of publicly-held firms. Eisenberg et al. (1998) find a negative correlation between board size and performance for small firms with small boards in Finland. Dimopouslos and Wagner (2010) assert that board size plays an important role in whether firm-level governance matters or not in improving firm performance following CEO turnover. Although the overwhelming evidence points to a positive association between performance and smaller board size, the evidence is not unanimous. For example, Faleye (2003) does not find significant differences in the sensitivity of CEO turnover to performance based on the board size. Faleye suggests that both small and large boards are likely to terminate the CEO when faced with significant and consistent deterioration in performance.

Turning to private firms, Dalton et al. (1999) provide "systematic evidence of nonzero, positive, true population estimates of board size-performance relationships" (p.674). Jaffe and Lane (2004) too characterize larger board as an indicator of good governance. Based on Jaffe and Lane (2004) and Coles et al. (2008), we predict a positive relationship between a multifamily firm and its board size and therefore, its performance. We measure the board size by the number of members on the board.

Outsiders $^{6}$ on the audit committee The role of an audit committee in the context of Indian firms, by and large, can be summarized as: (1) oversight of financial reporting and accounting, (2) oversight of the external auditor, (3) oversight of regulatory compliance, (4) monitoring the internal control process and (5) oversight of risk management.

The same reason as to why multifamily firms choose higher outside representation on the board might equally apply to their preference for outside representation on the audit committee as the presence of outsiders on the audit committee is also a sign of independence of the committee, since outsiders generally do not depend on the management for promotion or other such benefits. We believe that multifamily firms are more likely than single-family firms to seek out an outsider on the audit committee as a means to counteract potential interfamily conflicts.

Outsiders in audit committee play a significant role in ensuring good governance practices. Anderson et al. (2004) observe that firms with exclusively independent audit committees have lower debt financing costs. We hypothesize that the presence of an external auditor(s) would be positively related to the performance of this firm. Given the nearly invariant size of auditing committee, we construct a dummy variable that takes on the value of 1 if the firm has an outsider on the audit committee (Outsiders on the Audit Committee), and 0 otherwise.

Based on the discussions above, we provide below a summary of the predicted relationship between the organization and the governance structure it chooses as well as between the chosen structure and the performance of this organization.

\footnotetext{
$\overline{{ }^{6}}$ We use the two terms "independent" and "outsider" interchangeably.
} 


\begin{tabular}{|c|c|c|}
\hline $\begin{array}{l}\text { Governance } \\
\text { Variables }\end{array}$ & Hypothesis 1 & Hypothesis 2 \\
\hline Duality & $\begin{array}{l}\text { An MF would be characterized by the } \\
\text { absence of duality. }\end{array}$ & $\begin{array}{l}\text { The effect of duality on the MF's performance } \\
\text { needs to be empirically determined. }\end{array}$ \\
\hline $\begin{array}{l}\text { Independent } \\
\text { Director }\end{array}$ & $\begin{array}{l}\text { An MF's board would consist of a larger } \\
\text { percentage of independent directors. }\end{array}$ & $\begin{array}{l}\text { Greater presence of independent directors would } \\
\text { be positively associated with the performance } \\
\text { of the MF.. }\end{array}$ \\
\hline Board Size & $\begin{array}{l}\text { The board size of an MF would be } \\
\text { larger than that of a SF. }\end{array}$ & $\begin{array}{l}\text { Greater board size will be positively associated } \\
\text { with the performance of an } \mathrm{MF} \text {. }\end{array}$ \\
\hline $\begin{array}{l}\text { Outsider on } \\
\text { Audit } \\
\text { Committee }\end{array}$ & $\begin{array}{l}\text { The audit committee of an MF would } \\
\text { contain an outsider(s). }\end{array}$ & $\begin{array}{l}\text { The presence of independent auditors would be } \\
\text { positively correlated with the performance of an } \\
\text { MF. }\end{array}$ \\
\hline
\end{tabular}

$\mathrm{MF}=$ Multifamily; SF = Single-family

\subsubsection{Control variables}

In order to isolate the contributions of the governance variables on the firm's performance, we also control for other variables that might influence a firm's performance. These variables are defined below.

Firm size The effect of a firm's size on its performance has been a subject of debate. On one hand, the greater size allows the firm greater economies of scale and negotiating power, lowering the cost of capital, and improving the firm performance. On the other hand, the bigger the size of the firm, the greater is the potential for information asymmetry between managers and owners and thus increased chances for exploitation by managers. The net effect of the size on a firm's performance could be either positive or negative. Maury (2006) reports that the size of the firm has a positive effect on its performance, while Majumdar (1997) documents that in India, larger firms are more profitable but less productive than smaller counterparts. We measure asset size by the logarithm of total assets of the firm.

Firm age A firm's age is related to its lifecycle which might impact a firm's growth potential and its performance. There is limited evidence in the literature on how the age affects a firm's performance. Loderer and Waelchli (2010) indicate a weak negative relationship between firm age and profitability. Majumdar (1997) finds that Indian companies become more productive but less profitable as they age.

Manufacturing firm dummy Much of the firm performance depends on the nature of its principal economic activity. The dummy variable takes on a value of one if a firm operates in the manufacturing sector, and zero otherwise.

Table 2 provides definitions of the variables used in this study. 
Table 2 Variable definitions

\begin{tabular}{|c|c|}
\hline Variable & Definition \\
\hline \multicolumn{2}{|l|}{ Ownership } \\
\hline Multifamily firm dummy & $\begin{array}{l}\text { A dummy variable that takes the value of } 1 \text { for a multifamily firm, } \\
\text { and the value of } 0 \text { for a single-family firm. }\end{array}$ \\
\hline \multicolumn{2}{|l|}{ Performance } \\
\hline Return on assets (ROA) & $\begin{array}{l}\text { Net income/average total assets, where assets is the average of the } \\
\text { levels at the start and the end of a year. }\end{array}$ \\
\hline Return on equity (ROE) & $\begin{array}{l}\text { Net income/average total equity, where equity is the average of the } \\
\text { levels at the start and the end of a year. }\end{array}$ \\
\hline \multicolumn{2}{|l|}{ Corporate govemance } \\
\hline Duality & $\begin{array}{l}\text { A dummy variable that is equal to } 1 \text { if the CEO and the board } \\
\text { chairperson are from the same family, and } 0 \text { otherwise. }\end{array}$ \\
\hline$\%$ Outside directors & Proportion of outside (i.e., unrelated to families) directors on the board. \\
\hline Board size & Number of directors on a firm's board. \\
\hline Outsiders on auditing committee & $\begin{array}{l}\text { A dummy variable that takes the value of } 1 \text { if the firm has outsiders } \\
\text { on the audit committee, and } 0 \text { otherwise. }\end{array}$ \\
\hline \multicolumn{2}{|l|}{ Other firm characteristic } \\
\hline Firm size & Log of the total assets. \\
\hline Firm age & Age of the firm (in years). \\
\hline Manufacturing firm dummy & $\begin{array}{l}\text { A dummy variable that takes the value of } 1 \text { for a manufacturing firm } \\
\text { and } 0 \text { otherwise. }\end{array}$ \\
\hline
\end{tabular}

This table provides the description of variables used in the paper.

\subsection{Data}

The data for this paper are hand-collected from responses of CEOs (or Board Chairs) of 83 USOSFs to a pretested questionnaire. The questionnaire consists of data items that help us capture useful information about these sample firms during 2008-2010. We collect four types of information: a) the ownership structure, such as whether the firm is owned by a single family or multiple families, b) general firm characteristics such as industry, age, and size, c) accounting information to estimate profitability, i.e., ROA and ROE, and d) governance proxies, such as board size, number of outside directors, and outsiders on audit committee.

\subsection{Methodology}

We use both univariate and multivariate procedures to test our hypotheses. In terms of multivariate procedures, we first estimate the models using OLS with clustered standard errors. In the event we find that multifamily firms outperform 
single-family firms, we need to show that the superior performance is owed to their better governance structure. In so doing, we employ a mediation model in which the ownership structure determines the governance choice, which in turn influences performance. In principle, mediation is believed to exist when the causal effect of an independent variable $(\mathrm{X})$ on a dependent variable $(\mathrm{Y})$ is transmitted by a mediator $(\mathrm{M})$. The Graphical representation of mediation is as follows.

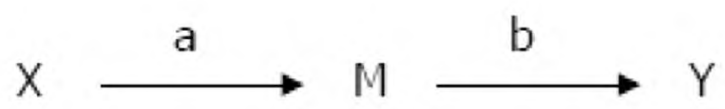

The intervening variable $M$ mediates between the explanatory variable $X$ and the dependent variable Y. Paths $a$ and $b$ are the direct effects. The meditational effect as $\mathrm{X}$ leads to $\mathrm{Y}$ through $\mathrm{M}$, is the indirect effect. The indirect effect represents the fraction of the relationship between $X$ and $Y$ that is mediated by M. In order to test for mediation, Baron and Kenny (1986) propose a four-step model in which regressions are run and the significance of the coefficients is examined at each step:

\section{Step 1:}

To run a regression analysis with $\mathrm{X}$ predicting $\mathrm{Y}$ to test for path $\mathrm{c}$ alone using the equation:

$$
Y=\beta_{0}+\beta_{1} X+\varepsilon
$$

$\mathrm{a}$

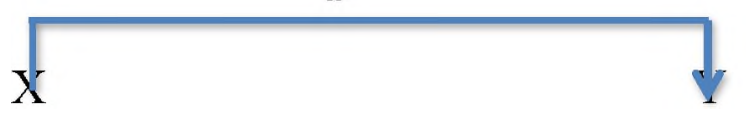

Step 2:

To run a regression analysis with $\mathrm{M}$ predicting $\mathrm{Y}$ to test for the significance of the path $b$ using the equation:

$$
Y=\beta_{0}+\beta_{1} M+\varepsilon
$$

b 
Step 3:

To run a regression analysis with $X$ predicting $M$ to test for the path a using the equation:

$$
M=\beta_{0}+\beta_{1} X+\varepsilon
$$

C

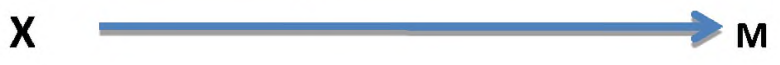

Step 4:

To run a regression analysis with $\mathrm{X}$ and $\mathrm{M}$ predicting $\mathrm{Y} \mathrm{b}$ using the equation:

$$
Y=\beta_{0}+\beta_{1} X+\beta_{2} M+\varepsilon
$$

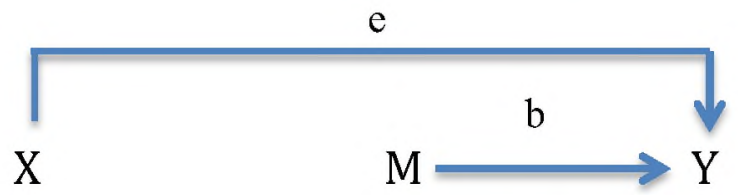

\section{Results}

\subsection{Summary statistics}

We report in Table 3 the summary statistics of the variables employed in this paper. The sample firms, in general, exhibit high operating performance, with the ROA and ROE is averaging 0.277 and 0.575 , respectively. Considerable variations though exist across firms, with ROA ranging from 0.01 to 0.96 and ROE ranging from 0.02 to 1.93 . An average board has 7 directors, out of which only 1.4 are from outside the owning families. The proportion of outside directors ranges from 0.173 , and 0.333 , with some firms having no outside directors. On average, the auditing committee has less than one outsider. Duality prevails in 59\% of firms in our sample. Firm age ranges from 3 years to 40 years, with the average being 14 years. Nearly $80 \%$ of sample firms operate in the manufacturing industry.

Table 4 shows the correlation coefficients among variables. The following observations are worth noting. First, both ROA and ROE are positively correlated with the multifamily dummy. Second, governance measures also relate positively to performance measures. Third, a positive relationship exists between the percentage of outsiders and the board size on one hand, and with the presence of outside auditors on the other. Fourth, the firm size is negative, while the firm's age and manufacturing 
Table 3 Descriptive statistics

\begin{tabular}{llllll}
\hline & Mean & Median & Std Dev & Minimum & Maximum \\
\hline $\begin{array}{l}\text { Ownership structure } \\
\text { Multifamily firm dummy }\end{array}$ & 0.386 & 0 & 0 & 0 & 1 \\
Firm Performance & & & & & \\
ROA & 0.277 & 0.210 & 0.208 & 0.010 & 0.960 \\
ROE & 0.575 & 0.480 & 0.361 & 0.020 & 1.930 \\
Corporate Governance & & & & & 1 \\
Duality & 0.578 & 1 & 0.495 & 0 & 0.333 \\
$\quad$ \%Outside directors & 0.173 & 0.2 & 0.109 & 0 & 15 \\
Board size & 7.120 & 7 & 3.109 & 3 & 1 \\
$\quad$ Outsiders on auditing committee & 0.578 & 1 & 0.495 & 0 & 3145 \\
Firm characteristics & & & & & 40 \\
Total assets (million INR) & 698 & 278 & 777 & 96 & 1 \\
Firm age & 14.18 & 11 & 8.48 & 3 & 0 \\
Manufacturing firm dummy & 0.795 & 1 & 0.404 & 0 & \\
\hline
\end{tabular}

Exchange rates: March 2008: 1USD=40.22 INR March 2009: 1USD=51.18 INR March 2010: 1USD = 45.48 INR

This table presents the descriptive statistics of main variables used in the paper. Ownership structure is represented by a dummy variable that is equal to one for multifamily firms and zeroes otherwise. Firm performance is measured by return on assets (ROA) and return on equity (ROE). Governance variables include board size, the number of outside directors on the board, the number of outside directors on the auditing committee, and a dummy variable that is equal to one if a founding family member assumes both the $\mathrm{CEO}$ and board Chair positions, and zero otherwise. Firm characteristics are total assets, firm age, and whether the firm is in the manufacturing industry

affiliation are positively related to performance measures. Finally, the multifamily dummy relates positively to all variables with the exceptions of duality and firm size. The negative relation of the dummy with duality suggests that the duality is more common to single-family firms.

Table 4 Correlations
(1)
(2)
(3)
(4)
(5)
(6)
(7)
(8)
(9)

(1) $\mathrm{ROA}$

(2) $\mathrm{ROE}$

0.85

(3) Multifamily dummy

$0.40 \quad 0.29$

(4) Duality

$\begin{array}{lll}0.24 & 0.26 & -0.23\end{array}$

(5) \%Outside directors

$0.51 \quad 0.56$

$0.15 \quad 0.00$

(6) Board size

$0.85 \quad 0.91$

$0.37 \quad 0.22$

0.56

(7) Outsiders auditing

$\begin{array}{lllll}0.63 & 0.71 & 0.28 & 0.16\end{array}$

0.48

0.75

(8) $\log$ (assets)

$-0.30 \quad-0.21$

$-0.67 \quad 0.26$

$-0.03$

$0.28-0.22$

(9) Firm age

$0.33 \quad 0.28$

$\begin{array}{ll}0.32 & 0.17\end{array}$

$-0.01$

$0.30 \quad 0.29$

$-0.19$

(10) Manufacturing dummy

$0.17 \quad 0.15$

$0.22-0.07$

0.15

$\begin{array}{lll}0.23 & 0.17 & -0.08\end{array}$

0.12 


\subsection{Testing hypothesis 1: Governance structure - single-family vs. multifamily firms}

\subsubsection{Univariate analysis}

The Univariate results reported in Table 5 show the differences in the governance structures between the two groups. Compared to single-family firms, multifamily firms have larger boards ( 8.6 directors vs. 6.2 directors on average), more outside directors on board ( 1.87 vs 1.14 on average) and more outsiders in the auditing committee (.75 vs. 0.47 ), and these differences are all statistically significant at the $1 \%$ level. The results of differences in median tests replicate the results of the differences in mean tests. To sum up, the results in Table 5 are in line with our expectations about the governance systems pertaining to the two groups of families.

Table 5 also presents the performance comparison between single-family and multifamily firms in our sample. First and foremost, multifamily firms significantly outperform their single-family counterparts regardless of the measure. The average ROA and ROE are 0.211 and 0.493 , respectively, for single-family firms, and 0.382 and 0.706 , respectively, for multifamily firms. The medians are 0.150 and 0.325 , respectively, for single-family firms, but much higher at 0350 and 0.770 for multifamily firms. The across-group differences in both the mean and median are statistically significant at the $1 \%$ level.

\subsubsection{Multivariate analyses}

To perform multivariate analyses, we run regressions of Indian UFOSFs' operating performance on its ownership structure and governance to tease out what drives the better performance of multifamily firms. Dependent variables are ROA and ROE, respectively. Control variables include the firm's size, age, and industry affiliation. We employ three specifications: Specification (1) uses only ownership structure and control variables as independent variables, specification (2) uses only governance and control variables as independent variables, and specification (3) uses all variables. This design helps reveal which, ownership structure or governance, drives the discrepancy in performance across single- and multifamily firms. The models are estimated using OLS with clustered standard errors. Table 6 reports estimation results.

The foremost observation is that the ownership structure loads positively in the specification (1) but does not load in the specification (3), while governance variables have very similar coefficients with similar statistical significance across specifications (2) and (3), especially with respect to ROA. In particular, in the specification (1) the multifamily dummy receives a positive coefficient of 0.108 in the ROA regression and 0.130 in the ROE regression, both statistically significant at the $10 \%$ level, indicating superior performance of multifamily to single-family firms. In specification (2), out of the four governance measures, board size and percent of outside directors have statistically significant coefficients with a positive sign.

In specification (3) when both ownership structure and governance variables are included, the coefficient of ownership declines to 0.043 in the ROA regression and0.012 in the ROE regression, neither significantly different from zero. In contrast, board size, percent of outside directors and duality all have coefficients that barely changed 
Table 5 Comparison of single-family vs. multifamily firms

\begin{tabular}{|c|c|c|c|c|c|c|c|c|}
\hline & \multicolumn{4}{|l|}{ Mean } & \multicolumn{4}{|l|}{ Median } \\
\hline & \multirow[t]{2}{*}{ Single-family } & \multirow[t]{2}{*}{ Multifamily } & \multicolumn{2}{|c|}{ Test for different means } & \multirow[t]{2}{*}{ Single-family } & \multirow[t]{2}{*}{ Multifamily } & \multicolumn{2}{|c|}{ Test for different medians } \\
\hline & & & $\mathrm{t}$ & $\operatorname{Pr}>t$ & & & $Z$ & $\operatorname{Pr}>Z$ \\
\hline \multicolumn{9}{|l|}{ Performance } \\
\hline $\mathrm{ROA}$ & 0.211 & 0.382 & 6.06 & $<0.001$ & 0.150 & 0.325 & 3.56 & $<0.001$ \\
\hline ROE & 0.493 & 0.706 & 4.46 & $<0.001$ & 0.350 & 0.770 & 4.21 & $<0.001$ \\
\hline \multicolumn{9}{|l|}{ Corporate governance } \\
\hline Duality & 0.667 & 0.438 & 3.64 & $<0.001$ & 1 & 1 & 3.56 & $<0.001$ \\
\hline Outside directors & 1.138 & 1.875 & 4.77 & $<0.001$ & 1 & 2 & 3.72 & $<0.001$ \\
\hline Board size & 6.216 & 8.563 & 6.05 & $<0.001$ & 5 & 8.5 & 4.43 & $<0.001$ \\
\hline Outsiders on auditing committee & 0.471 & 0.750 & 4.50 & $<0.001$ & 0 & 1 & 4.34 & $<0.001$ \\
\hline \multicolumn{9}{|l|}{ Firm characteristics } \\
\hline Log(assets) & 15.67 & 13.85 & 14.60 & $<0.001$ & 15.28 & 14.08 & -9.83 & $<0.001$ \\
\hline Firm age & 12.02 & 17.63 & 4.84 & $<0.001$ & 8 & 18 & 3.88 & $<0.001$ \\
\hline Manufacturing firm dummy & 0.726 & 0.906 & 3.85 & $<0.001$ & 1 & 1 & 3.43 & $<0.001$ \\
\hline
\end{tabular}

This table presents the differences between single-family and multifamily firms in operating performance, corporate governance and other characteristics. ROA and ROE measure operating performance, a multifamily firm is a dummy that takes on a value of 1 , corporate governance variables are represented by the board size, the proportion of outside directors on the board, presence of outsiders on the auditing committee, and duality (whether the CEO and board Chair are from the same family). Control variables are the firm's size, age, and industrial affiliation. Detailed variable definitions are provided in Table 2. Means and medians of the variables are reported and their differences across the groups are tested using the two-sample t-test and the Mann Whitney U test, respectively 
Table 6 Ownership structure, corporate governance, and operating performance

\begin{tabular}{|c|c|c|c|c|c|c|}
\hline \multirow[t]{2}{*}{ Dependent Variable } & \multicolumn{3}{|l|}{ ROA } & \multicolumn{3}{|l|}{ ROE } \\
\hline & 1) & (2) & (3) & (1) & (2) & (3) \\
\hline \multirow[t]{2}{*}{ Multifamily firm dummy } & $0.108^{*}$ & & 0.043 & $0.130^{*}$ & & -0.012 \\
\hline & $(0.059)$ & & $(0.032)$ & $(0.075)$ & & $(0.047)$ \\
\hline \multicolumn{7}{|l|}{ Governance Variables } \\
\hline \multirow[t]{2}{*}{ Duality } & & 0.043 & $0.048^{*}$ & & 0.038 & 0.037 \\
\hline & & $(0.027)$ & $(0.027)$ & & $(0.033)$ & $(0.031)$ \\
\hline \multirow[t]{2}{*}{$\%$ Outside directors } & & $0.208 *$ & $0.201^{*}$ & & 0.261 & 0.263 \\
\hline & & $(0.108)$ & $(0.110)$ & & $(0.178)$ & $(0.180)$ \\
\hline \multirow[t]{2}{*}{ Board size } & & 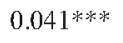 & 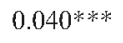 & & 0.097 **** & 0.097 *** \\
\hline & & $(0.007)$ & $(0.007)$ & & $(0.012)$ & $(0.012)$ \\
\hline \multirow[t]{2}{*}{ Outsiders on auditing committee } & & 0.039 & 0.039 & & 0.037 & 0.036 \\
\hline & & $(0.033)$ & $(0.033)$ & & $(0.054)$ & $(0.054)$ \\
\hline \multicolumn{7}{|l|}{ Firm Characteristics } \\
\hline \multirow[t]{2}{*}{ Log(Assets) } & -0.014 & $-0.017^{*}$ & -0.009 & -0.012 & 0.006 & 0.004 \\
\hline & $(0.020)$ & $(0.010)$ & $(0.011)$ & $(0.036)$ & $(0.011)$ & $(0.014)$ \\
\hline \multirow[t]{2}{*}{ Firm age } & $0.005^{* *}$ & 0.002 & 0.001 & $0.009 * *$ & 0.001 & 0.001 \\
\hline & $(0.003)$ & $(0.002)$ & $(0.002)$ & $(0.004)$ & $(0.002)$ & $(0.002)$ \\
\hline \multirow[t]{2}{*}{ Manufacturing firm dummy } & 0.044 & -0.008 & -0.013 & 0.071 & $-0.056^{*}$ & $-0.054 *$ \\
\hline & $(0.039)$ & $(0.020)$ & $(0.022)$ & $(0.074)$ & $(0.030)$ & $(0.031)$ \\
\hline \multirow[t]{2}{*}{ Intercept } & 0.300 & 0.109 & -0.020 & 0.494 & -0.286 & -0.249 \\
\hline & $(0.313)$ & $(0.154)$ & $(0.179)$ & $(0.568)$ & $(0.176)$ & $(0.239)$ \\
\hline Year fixed effects & Yes & Yes & Yes & Yes & Yes & Yes \\
\hline $\mathrm{R}^{2}$ & 0.226 & 0.760 & 0.764 & 0.133 & 0.843 & 0.843 \\
\hline
\end{tabular}

This table presents the regression of Indian family firms' operating performance on their ownership structures and governance. ROA and ROE measure operating performance, a multifamily firm is a dummy that takes on a value of 1 , governance variables are represented by the board size, the proportion of outside directors on the board, presence of outsiders on the on the auditing committee, and duality (whether the CEO and board Chair are from the same family). Control variables are the firm's size, age, and industrial affiliation. Detailed variable definitions are provided in Table 2 . The model is estimated using OLS, with clustered standard errors reported under the coefficient estimates. $*^{* *}$, and $*^{*} *$ mark statistical significance at the 10,5 , and $1 \%$ levels, respectively

across specifications. Among these governance variables, board size receives coefficients that are positive and statistically significant at the $1 \%$ level in both ROA and $\mathrm{ROE}$ regressions. The proportion of outsiders on the board and duality ${ }^{7}$ both obtain positive coefficients in the ROA regressions that are statistically significant at the $10 \%$ level. The combined evidence in Table 6 indicates that governance, and not the ownership structure itself, drives the performance difference between single-family and multifamily firms.

\footnotetext{
${ }^{7}$ Selection of the member(s) of the same family to perform both CEO and board chair functions might reflect the trust other families have for the superior management skills of the entrusted family.
} 
The $\mathrm{R}^{2}$ 's of the regressions are informative of the explanatory power of the models. In specification (1), the $\mathrm{R}^{2}$ is 0.226 in the ROA regression and 0.133 in the ROE regression. In specifications (2) and (3) where governance variables are introduced, the $\mathrm{R}^{2}$ jumps to a much higher level (between 0.76 and 0.84 ), indicating that governance contributes a great majority of the explanatory power of the set of explanatory variables.

Out of the control variables, the coefficient of firm size is significant (at the $10 \%$ level) and negative only in the specification (2) with ROA as the dependent variable, meaning that as size increases the performance deteriorates for multifamily firms. A firm's age loads positively and significantly in the specification (1) for both ROA and ROE. However, its effects on the firm's performance appear to be subsumed by governance factors in the specification (2) or (3). Thus, neither size nor age is the main determinant of firm performance. The coefficient of manufacturing firms dummy is not different from zero in the ROA regression but is negative and statistically significant in the ROE regression in the presence of governance variables. This particular finding might serve as further evidence that effect of better governance of multifamily firms is strong enough to outweigh the negative performance of manufacturing firms that are more intensely $(90 \%)$ populated by multifamily firms.

To sum up, the multivariate analysis shows that a multifamily firm's better governance system, and not the ownership structure, is what drives its superior performance. Specifically, larger board, a greater presence of outside directors on the board, and a higher number of members on the audit committee help strike a balance of power among all related families and promotes the common objective of maximizing the firm's profit.

\subsection{Mediation model}

To verify the indirect effect of multifamily ownership structure on firm performance via corporate governance system installed, we perform a robustness check using the conditional mediation approach. Following Baron and Kenny (1986), we formulate our analysis by running the following four-stage regressions:

$$
\begin{aligned}
& \text { Performance }_{j t} \\
& \quad=\beta_{0}+\beta_{1} \text { Duality }_{j t}+\beta_{2} \text { Outside Directors }_{j t}+\beta_{3} \text { Board Size }_{j t} \\
& +\beta_{4} \text { Outsiders on Auditing Committe }_{j t}+\beta_{5} \text { Log of Assets }_{j t} \\
& +\beta_{6} \text { Firm Age }_{j t}+\beta_{7} \text { Manufacturing firm }_{j t}+\mu_{j}+\nu_{t}+\varepsilon_{j t}
\end{aligned},
$$

where $\mu^{t}$ is firm-specific fixed effects; $\nu_{t}$ is time-fixed effects; and $\varepsilon_{j}^{t}$ is the unobservable error term.

$$
\begin{aligned}
& \text { Performance }_{j t} \\
& \quad=\beta_{0}+\beta_{1} \text { Multifamily firm }_{j t}+\beta_{2} \text { Log of Assets }_{j t}+\beta_{3} \text { Firm Age }_{j t}, \\
& \quad+\beta_{4} \text { Manufacturing firm }_{j t}+\mu_{j}+\nu_{t}+\varepsilon_{j t}
\end{aligned}
$$


Multifamilyfirm $m_{j t}$

$=\beta_{0}+\beta_{1}$ Duality $_{j t}+\beta_{2}$ Outside Directors $_{j t}+\beta_{3}$ Board Size $_{j t}$

$+\beta_{4}$ Outsiders on Auditing Committee $_{j t}+\beta_{5}$ Log of Assets $_{j t}$

$+\beta_{6}$ Firm Age $_{j t}+\beta_{7}$ Manufacturing firm $_{j t}+\mu_{j}+\nu_{t}+\varepsilon_{j t}$

and,

Performance $_{j t}$

$=\beta_{0}+\beta_{1}$ Duality $_{j t}+\beta_{2}$ Outside Directors $_{j t}+\beta_{3}$ Board Size $_{j t}$

$+\beta_{4}$ Outsiders on Auditing Committee ${ }_{j t}+\beta_{5}$ Multifamily firm $_{j t}$

$+\beta_{6} \log$ of Assets A $_{j t}+\beta_{7}$ Firm Age $_{j t}+\beta_{8}$ Manufacturing firm $_{j t}+\mu_{j}+\nu_{t}$ $+\varepsilon_{j t}$

Table 7 reports the results of the regressions. Board size, outside directors, and duality have a significant positive influence on ROA and ROE of the firms, shown in columns $1,4,5$, and 8 . Results in columns 2 and 6 suggest that a multifamily firm is associated a larger board and a lower likelihood of that both $\mathrm{CEO}$ and board Chairperson come from the same family. Columns 3 and 7 exhibit a significantly positive relationship between the multifamily firm and performance. Finally, columns 4 and 8 report a significantly positive impact on the combined governance and multifamily firm on the firm's performance.

To sum up, first, the larger the board size the better is the performance (significant at the $1 \%$ level) in all specifications. Second, a greater percentage of outside directors is significantly positively related to the performance. Finally, the duality imparts a positive effect in the case of multifamily firms. In general, the results of robustness tests confirm that a better governance system designed to reduce agency problems for a multifamily private firm serves its intended purpose by contributing positively to its performance.

\subsection{Endogeneity issue}

Endogeneity notoriously inflicts most governance research in the forms of simultaneity or omitted variables (Roberts and Whited 2013). A similar concern might be expressed about our research. A relevant question is: does multifamily ownership, improve the performance or is it the improved performance that attracts more families to the firm? Jaffe and Lane (2004) depict a clear picture of the transition from a single-family to a multifamily firm. The family business starts with the founder as the owner/manager, then it takes on the partnership form as it is passed on to succeeding generations, and finally, the business becomes a holding company with diversified assets owned by family branches. The existence of this succession process is borne out by the fact that the ownerships are equally divided among all owning families in our sample of multifamily firms. In short, it is the succession within and not the entry from outside that determines the ownership structure of family-owned private firms in India. Thus, simultaneity does not appear to be a concern for our study. In spite of controlling for firm size, age, and industry classification, all known as important determinants of firm performance, we cannot rule out the possibility of the omitted variables bias. Absent publicly available data, we admit that this list of control variables is probably not exhaustive. 
Table 7 Mediation effect of ownership structure through governance

\begin{tabular}{|c|c|c|c|c|c|c|c|c|}
\hline $\begin{array}{l}\text { Direction of } \\
\text { mediation } \rightarrow\end{array}$ & $\begin{array}{l}\text { Governance } \\
\rightarrow \text { ROA }\end{array}$ & $\begin{array}{l}\text { Governance } \\
\rightarrow \text { Multifamily } \\
\text { firm }\end{array}$ & $\begin{array}{l}\text { Multifamily } \\
\text { firm } \rightarrow \mathrm{ROA}\end{array}$ & $\begin{array}{l}\text { Govemance \& } \\
\text { Multifamily firm } \\
\rightarrow \text { ROA }\end{array}$ & $\begin{array}{l}\text { Governance } \\
\rightarrow \mathrm{ROE}\end{array}$ & $\begin{array}{l}\text { Governance } \\
\rightarrow \text { Multilamily } \\
\text { firm }\end{array}$ & $\begin{array}{l}\text { Multifamily } \\
\text { firm } \rightarrow \text { ROI }\end{array}$ & $\begin{array}{l}\text { Governance \& } \\
\text { Multifamily firm } \\
\rightarrow \text { ROE }\end{array}$ \\
\hline \multirow[t]{2}{*}{ Dependent variable $\Rightarrow$} & ROA & Multifamily firm & $\mathrm{ROA}$ & ROA & ROE & Multifamily firm & ROE & $\mathrm{ROE}$ \\
\hline & (1) & (2) & (3) & (4) & (5) & (6) & (7) & (8) \\
\hline \multirow[t]{2}{*}{ Duality } & $0.045^{* * *}$ & -0.159 & & $0.052^{* * *}$ & $0.048^{* *}$ & -0.159 & & $0.044^{* * *}$ \\
\hline & $(0.013)$ & $(0.008)$ & & $(0.013)$ & $(0.018)$ & $(0.008)$ & & $(0.006)$ \\
\hline \multirow[t]{2}{*}{ \%Outside directors } & $0.075^{* * *}$ & $0.016^{* * *}$ & & $0.074^{* * *}$ & $0.071^{* * *}$ & $0.016^{* * *}$ & & $0.070^{* * *}$ \\
\hline & $(0.011)$ & $(0.004)$ & & $(0.011)$ & $(0.019)$ & $(0.004)$ & & $(0.015)$ \\
\hline \multirow[t]{2}{*}{ Board Size } & $0.022^{* * * *}$ & $0.028 * * *$ & & $0.021^{* * *}$ & $0.070 * * *$ & $0.028 * * *$ & & $0.071^{* * *}$ \\
\hline & $(0.005)$ & $(0.002)$ & & $(0.005)$ & $(0.011)$ & $(0.002)$ & & $(0.006)$ \\
\hline \multirow{2}{*}{$\begin{array}{l}\text { Outsiders on auditing } \\
\text { committee }\end{array}$} & 0.025 & -0.016 & & 0.025 & $0.057^{*}$ & -0.016 & & $0.057^{*}$ \\
\hline & $(0.017)$ & $(0.010)$ & & $(0.018)$ & $(0.032)$ & $(0.010)$ & & $(0.004)$ \\
\hline \multirow[t]{2}{*}{ Multifamily firm dummy } & & & $0.116^{* * *}$ & $0.039 * *$ & & & $0.145^{* * *}$ & $0.022 * *$ \\
\hline & & & $(0.0005)$ & $(0.018)$ & & & $(0.061)$ & $(0.012)$ \\
\hline \multirow[t]{2}{*}{$\log ($ Assets $)$} & $-0.017^{* * * *}$ & $-0.197^{* * * * *}$ & -0.012 & -0.010 & 0.007 & $-0.197 * * *$ & -0.009 & 0.002 \\
\hline & $(0.004)$ & $(0.010)$ & $(0.288)$ & $(0.006)$ & $(0.006)$ & $(0.010)$ & $(0.021)$ & $(0.006)$ \\
\hline \multirow[t]{2}{*}{ Firm Age } & $0.002^{* *}$ & $0.011^{* * *}$ & $0.005^{* * * *}$ & $0.001 *$ & 0.006 & $0.011^{\text {**** }}$ & $0.008^{* * *}$ & 0.008 \\
\hline & $(0.0009)$ & $(0.0005)$ & $(0.001)$ & $(0.0008)$ & $(0.001)$ & $(0.0005)$ & $(0.002)$ & $(0.0002)$ \\
\hline \multirow[t]{2}{*}{ Intercept } & $0.202^{* *}$ & $3.063^{*}$ 水 & $0.342^{*}$ & 0.084 & $-0.207^{*}$ & 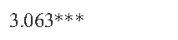 & 0.538 & -0.169 \\
\hline & $(0.08)$ & $(0.168)$ & $(0.185)$ & $(0.098)$ & $(0.111)$ & $(0.168)$ & $(0.340)$ & $(0.104)$ \\
\hline Year fixed effects & yes & yes & yes & yes & yes & yes & yes & yes \\
\hline $\mathrm{R}^{2}$ & 0.787 & 0.529 & 0.219 & 0.780 & 0.849 & 0.529 & 0.126 & 0.844 \\
\hline Obs & 249 & 249 & 249 & 249 & 249 & 249 & 249 & 249 \\
\hline
\end{tabular}

This table reports the results of the moderation regressions to show the moderation effect of the multifamily firm as a causal link between governance variables and the firm performance variables - ROA, and ROE. Column (1) and (5) show the results of Eq. (1) as impact runs from governance to firm performance. Column (2) and ((6) show the results of Eq. (3) where the impact runs from governance to multifamily firm. Col (3) and (7) show the results of Eq. (2) as the impact runs from multifamily firm to firm performance. Finally, Col (4) and (8) show the results of Eq. (4) as the combined impact the impact runs from governance \& multifamily firm to firm performance. The results are based on Panel Least Squares and fixed effects. We employ panel-corrected standard error (PCSE) estimates assuming that the disturbances are, by default, heteroskedastic and contemporaneously correlated across panels. The coefficient values are followed by the standard errors in the parentheses. *,**, and *** mark statistical significance at the 1,5 , and $10 \%$ levels, respectively 


\section{Conclusion}

A private firm owned and managed by a single-family should not have owner-manager conflicts. Jensen and Meckling (1976) argue that a formal governance mechanism is not only unnecessary but likely to impair this firm's performance. Opponents of this view argue that even though an owner-managed firm does not suffer from conflicts between the owner and the manager, it still incurs other agency costs, such as altruism, which in the absence of an appropriate governance mechanism should negatively affect its financial performance. A private firm owned and managed by multiple families is exposed to additional agency problems because of inter-family conflicts, but it has the incentive to institute an appropriate governance system to reduce these conflicts. Based on the empirical evidence supporting a positive association between a firm's governance system and its performance, we predict that a multifamily firm, owing to its better governance system, will outperform its single-family counterpart.

Employing hand-collected data from a sample of 83 small, unlisted, family-owned firms in India, we demonstrate that multifamily firms indeed institute more efficient governance mechanisms than their single-family counterparts and perform better than the latter group. The multivariate analyses show that a multifamily firm's better governance system, and not its ownership structure, is what drives its superior performance. Specifically, larger board, a greater presence of outside directors on the board, and a higher number of members on the audit committee help strike a balance of power among all related families and promote the common objective of maximizing the firm's profit. Another important finding of the paper is that duality, although significantly less prevalent than single-family firms, makes a positive contribution to the performance of multifamily firms. Overall, the paper demonstrates the efficacy of governance system in a business organization, even in a privately-held owner-managed firm.

\section{Appendix 1. Stages of Family Business Evolution}

\begin{tabular}{|c|c|c|c|}
\hline Generation & G1: Entrepreneur & $\begin{array}{l}\text { G2: Family } \\
\text { Partnership }\end{array}$ & G3: Business Dynasty \\
\hline Business form & Entrepreneurship & Maturing business & $\begin{array}{l}\text { Holding company or family office with } \\
\text { diversified assets }\end{array}$ \\
\hline Mode of control & Founder/owner/manager & Sibling team & Family branches \\
\hline Strategy & Personal vision & Renew business & Sustain profitability; generate new wealth \\
\hline $\begin{array}{l}\text { Governance } \\
\text { structure }\end{array}$ & ad hoc, implicit & $\begin{array}{l}\text { Informal board, } \\
\text { implicit }\end{array}$ & Board with outsiders, formal policies \\
\hline
\end{tabular}

Source: Jaffe and Lane, Family Business Review, Vol. XVII, No. 1, March 2004. 


\section{Appendix 2. Regional Distribution of the Sample}

This table provides geographical distribution of the 83 UFOSFs. The sample consists of UFOSFs from 18 provinces in all the five regions of India. The number of firms in each province is shown in parentheses.

\begin{tabular}{lllll}
\hline Central Region & Eastern Region & Western Region & Northern Region & Southern Region \\
\hline Chhattisgarh (2) & Assam (3) & Gujarat (7) & Haryana (4) & Andhra Pradesh (5) \\
Jharkhand (2) & Bihar (2) & Maharashtra (9) & Himachal Pradesh (2) & Karnataka (4) \\
Madhya Pradesh (4) & Orissa (3) & Rajasthan (4) & Punjab (8) & Kerala (4) \\
& West Bengal 10) & & Uttar Pradesh (6) & Tamil Nadu (4) \\
Total (8) & Total (18) & Total (20) & Total (20) & Total (17) \\
\hline
\end{tabular}

Publisher's Note Springer Nature remains neutral with regard to jurisdictional claims in published maps and institutional affiliations.

\section{References}

Anderson CA, Anthony RN (1986) The new directors. John Wiley and Sons, New York

Anderson RC, Reeb DM (2003) Founding-family ownership and firm performance: evidence from the S\&P 500. J Financ 58:1301-1328

Anderson RC, Mansi S, Reeb DM (2004) Board characteristics, accounting report integrity and the cost of debt. J Account Econ 37:315-342

Baron RM, Kenny DA (1986) The moderator-mediator variable distinction in social psychological research: conceptual, strategic and statistical considerations. J Pers Soc Psychol 51:1173-1182

Berg SV, Smith SK (1978) CEO and board chairman: a quantitative study of dual v. unitary board leadership. Directors and Boards 3:34-49

Bhagat S, Bolton B, Romano R (2008) The promise and peril of governance indices. Colum L Rev 108:18031882

Brickley JA, Coles JL, Jarrell G (1997) Leadership structure: separating the CEO and chairman of the board. J Financ 3:189-220

Castaldi R, Wortman MS (1984) Board of directors in small corporations: an untapped resource. Am J Bus 9(2):1-11

Chaganti RS, Mahajan V, Sharma S (1985) Board size, composition, and failures in the retailing industry. J Manag Stud 22:400-417

Coles JL, Daniel ND, Naveen L (2008) Boards: does one size fit all? J Financ Econ 87:329-356

Daily CM, Dalton DR (1992) The relationship between govemance structure and performance in entrepreneurial firms. J Bus Ventur 7(5):375-386

Dalton DR, Daily CM, Johnson JL, Ellstrand AE (1999) Number of directors and financial performance: a meta-analysis. Acad Manag J 42(6):674-686

Dimopoulos T, Wagner HF (2010) Cause and effect in CEO changes, working paper, http://www.csef.it/6th c6/wagner.pdf

Dyer WG Jr (2006) Examining the "family effect" on firm performance. Fam Bus Rev 19(4):253-273

Eisenberg T, Sundgren S, Wells MT (1998) Larger board size and decreasing firm value in small firm. J Financ Econ 48:35-54

Faleye O (2003) Does One Hat Fit All? The Case of Corporate Leadership Structure. EFMA 2003 Helsinki Meetings. Available at SSRN: https://ssrn.com/abstract=394980 or https://doi.org/10.2139/ssrn.394980

Fama EF, Jensen MC (1983) Separation of ownership and control. J Law Econ 26:301-326

Ferris SP, Jagannathan M, Pritchard AC (2003) Too busy to mind the business: monitoring by directors with multiple board appointments. J Financ 58(3):1087-1112 
Gersick C, Hackman R (1990) Habitual routines in task-performing groups. Organizational Behavior and Human Decision Processes 47:65-97

Gopalan R, Nanda V, Seru A (2007) Affiliated firms and financial support: evidence from Indian business groups. J Financ Econ 86:759-795

Jaffe DT, Lane SH (2004) Sustaining a family dynasty: key issues facing complex multigenerational businessand investment-owning families. Fam Bus Rev 16:5-16

Jensen M (1993) The modern industrial revolution, exit, and the failure of internal control systems. J Financ 48:831-880

Jensen MC, Meckling WH (1976) Theory of the firm: managerial behavior, agency costs, and ownership structure. J Financ Econ 3:305-360

Khanna T, Palepu K (2000) Is group affiliation profitable in emerging markets? An analysis of diversified Indian business groups. J Financ 55:867-891

Lipton M, Lorsch J (1992) A modest proposal for improved governance. Bus Law 48(1):59-77

Loderer CF, Waelchli U (2010). Firm age and performance, Available at SSRN: http://ssrn. com/abstract=1342248. Accessed 26 Aug 2012

Majumdar SK (1997) The impact of size and age on firm-level performance: some evidence from India. Rev Ind Organ 12:231-241

Mak Y, Kusnadi Y (2005) Size really matters further evidence on the negative relationship between board size and firm value. Pac Basin Financ J 13:301-318

Maury B (2006) Family ownership and firm performance: empirical evidence from western European corporations. J Financ 12:321-341

Nguyen BD, Nielsen KM (2010) The value of independent directors: evidence from sudden deaths. J Financ Econ 98:550-567

Roberts MR, Whited MT (2013) Endogeneity in Empirical Corporate Finance, Handbook of the Economics of Finance, vol 2, Part A, 493-572

Rosenstein S, Wyatt JG (1990) Outside directors, board independence, and shareholder wealth. J Financ Econ 26:175-191

Sanda AU, Mikailu AS, Garba T (2005) Governance mechanisms and firm financial performance in Nigeria. Afro-Asian Journal of Finance and Accounting 2(1):22-39

Schulze WS, Lubatkin MH, Dino RN, Buchholtz AK (2001) Agency relationships in family firms: theory and evidence. Organ Sci 12:99-116

Steiner G, (1971) Business and society. New York: Random House

Tagiuri R, Davis J (1996) Bivalent attributes of the family firm. Fam Bus Rev 9(2): 199-208

Tajfel H (1982a) Social psychology of intergroup relations. Annu Rev Psychol 33:1-39

Tajfel H (1982b) Human groups and social categories. Cambridge University Press, Cambridge

Tajfel H, Turner J (1979). An integrative theory of intergroup conflict. In W.G. Austin\& S. Worchel (Eds.), (pp. 33-47): Brooks/Cole

Uhlaner L, Wright M, Huse M (2007) Private firms and governance: an integrated economic and management perspective. Small Bus Econ 29:225-241

Vance SC (1968) The Directors: Structure and Performance. University of Oregon Press, Eugene

Vance SC (1983) Leadership: boards, directors, and strategy. McGraw-Hill, New York

Yermack D (1996) Higher market valuation of companies with a small board of directors. J Financ Econ 40: $185-211$ 